\title{
Effects of Hunger Satiation on Diet Quality by Graz- ing Sheep
}

\author{
H.G. JUNG AND L.J. KOONG
}

\begin{abstract}
The effect of hunger satiation on selectivity for diet quality by sheep grazing a smooth bromegrass (Bromus inermis) pasture was studied with esophageal fistulated sheep. Fifteen wethers (45.8 \pm .7 $\mathrm{kg}$ ) were allotted to 5 treatments: nonfasted, fasted for $16 \mathrm{~h}$ and then fed $0,135,271$, or $\mathbf{4 0 7} \mathrm{g}$ of pelleted feed. Nonfasted animals were confined at $0800 \mathrm{~h}$ and sheep receiving pellets were fed at 0700 h. One animal from each treatment was included in groups released for grazing at 0900,0930 , and $1000 \mathrm{~h}$. Sheep grazed the smooth bromegrass pasture for $30 \mathrm{~min}$. The experiment was conducted on 4 consecutive days. Nonfasted sheep had a lower rate of intake than fasted animals (0 g pelleted feed) (47 vs. $124 \mathrm{mg} / \mathrm{min} / \mathrm{kg} \mathrm{BW}^{75}$, $P<.05)$, but the quality of the diet selected did not differ $(P>.05)$. All treatment groups selected diets of higher quality than the green fraction of the pasture collected by handelipping. Consumption of increasing quantities of pelleted feed by fasted animals resulted in linear $(P<.05)$ increases in in vitro dry matter disappearance and crude protein content of diet samples. Rate of forage intake and cell wall content of the ingested forage declined linearly $(P<.05)$ with increasing consumption of pelleted feed by previously fasted sheep. Composition of forage cell wall material in the diet samples also changed with pellet feeding, cellulose content increased while lignin content decreased. Overnight fasting of esophageal fistulated sheep did not influence selectivity for forage quality relative to nonfasted animals, but satiation of hunger, as a result of ingestion of a highly digestible feed after a fast, resulted in increased diet quality selected by the animals.
\end{abstract}

Sheep are well known for the selective nature of their grazing behavior (Arnold 1964). Leaf material is preferred to stems, and green fractions are consumed to. a greater degree than nongreen (Arnold 1960). The forage fractions preferred by sheep are also highest in nutritional quality (Terry and Tilley 1964, Griffin and Jung 1983). Diet collection by esophageal fistulated animals is generally regarded as the most accurate method of estimating dietary composition and quality of grazing animals (Van Dyne and Torell 1964). However, protocol varies among studies employing esophageal fistulated sheep and there is disagreement over the

Authors are research animal scientist and research leader, Production Systems Unit, USDA, ARS, Roman L. Hruska US Meat Animal Research Center, Clay Center, Neb. 68933. L.J. Koong's present address is Associate Director, College of Agriculture, University of Nevada, Reno 89557.

Manuscript accepted September 28, 1984. effects of fasting the fistulated animals. Arnold et al. (1964) cautioned that overnight fasting of esophageal sheep altered quality measurements of subsequent diet samples, whereas other work found no consistent changes in diet quality with moderate fasting (12-24 h) of sheep (Sidahmed et al. 1977).

Ivlev (1961), working with fish, established a concept widely accepted among ecologists that hunger alters the selective foraging behavior of animals. According to this theory, as an animal ingests fecd and satiation of its hunger is approached, it will become more and more selective in the food items it chooses to consume. In the case of sheep, this suggests that more preferred forage species and/or plant parts of higher nutritional quality will represent an ever increasing proportion of the total intake of an animal as its hunger is closer to being satiated.

The study reported here tested two hypotheses. First, that overnight fasting does not affect quality of the diet selected by esophageal fistulated sheep. The second hypothesis that was tested is that the degree to which a sheep's hunger is satiated affects diet selectivity, as measured by quality of the diet ingested.

\section{Materials and Methods}

Fifteen esophageal fistulated wethers $(45.8 \pm .7 \mathrm{~kg})$ were randomly allotted to 5 treatment groups; nonfasted, fasted for $16 \mathrm{~h}$ and then fed $0,135,271$ or $407 \mathrm{~g}$ of pelleted feed (See Table 1 for pelleted feed composition). Nonfasted animals were allowed to graze the smooth bromegrass (Bromus inermis) pasture overnight. Fasted animals were confined at $1500 \mathrm{~h}$, with access to water. At $0700 \mathrm{~h}$ of the following day, sheep in treatment groups to be fed received their allotted portions of pelleted feed. Nonfasted animals were removed from pasture at $0800 \mathrm{~h}$. One randomly selected animal from each treatment was released to graze at 0900,0930 , and $1000 \mathrm{~h}$. Each group of animals was allowed to graze a $1.2 \mathrm{ha}$ smooth bromegrass pasture for $30 \mathrm{~min}$. Extrusa from the esophageal fistula was collected in plastic bags to prevent loss of cell solubles by leaching. Diet samples contaminated with regurgitated rumen contents were discarded. Samples were frozen and lyophilized prior to analysis. The experiment was conducted on 4 consecutive days, 22-25 August 1983. All animals were allowed to graze the pastures after collection of diet samples until $1500 \mathrm{~h}$ of that day. The sheep were weighed after completing diet collections on the last day of the study. 
Table 1. Composition and in vitro dry matter disappearance (IVDMD) of pelleted feed.

\begin{tabular}{lc}
\hline \hline Item & Percent \\
\hline Ingredient & \\
Alfalfa hay & 45.0 \\
Corn & 45.0 \\
Soybean meal & 5.0 \\
Limestone & .5 \\
Trace mineral salt & .5 \\
Ammonium chloride & .5 \\
Vitamin A,D,E & .05 \\
Lignin-sulphate binder & 2.5 \\
Bone meal & 1.0 \\
Analysis & \\
Crude protein & 15.1 \\
Cell wall & 28.8 \\
IVDMD & 85.4 \\
\hline
\end{tabular}

The smooth bromegrass pasture was sampled on 22 August by clipping 30 quadrats $\left(.09 \mathrm{~m}^{2}\right)$ at ground level with hand shears. These samples were composited and the forage was sorted into green and nongreen fractions prior to being frozen and lyophilized.

Samples were ground to pass a 1-mm screen and analyzed for dry matter $\left(100^{\circ} \mathrm{C}\right)$, crude protein $(\mathrm{N} \times 6.25)$, and detergent fiber components (Goering and Van Soest 1970). Cell wall content $(\mathrm{CW})$, hemicellulose $(\mathrm{HC})$, cellulose (CEL), and lignin (LIG) were calculated from the detergent system $(\mathrm{CW}=$ neutral detergent fiber; $\mathrm{HC}=$ neutral detergent fiber-acid detergent fiber; $\mathrm{CEL}=$ acid detergent fiber-acid detergent lignin $72 \% \mathrm{H}_{2} \mathrm{SO}_{4} ; \mathrm{LIG}=$ acid detergent lignin $72 \% \mathrm{H}_{2} \mathrm{SO}_{4}$-ash). In vitro dry matter disappcarance was determined according to Tilley and Terry (1963). The rumen inoculum was obtained from a rumen fistulated steer, after an overnight fast, maintained on an alfalfa-grass hay.

The data were analyzed as a randomized complete block design. The data were blocked by day of the experiment. The data for the 4 fasted treatments were analyzed for linear trends with orthogonal contrasts.

\section{Results and Discussion}

The smooth bromegrass pasture used in this study had been grazed by 15 wether lambs per ha from 4 May to 11 August 1983. The esophageal fistulated wethers used in this experiment were maintained on the pasture from 11 August onward. The pasture was a virtual smooth bromegrass monoculture and had a standing biomass of $2,826 \mathrm{~kg} /$ ha on the first day of the experiment ( 22 August 1983) and contained $32.1 \%$ green material (Table 2). The green and nongreen fractions of the forage did not differ greatly in nutritional quality measurements (Table 2). The fiber fractions (HC, CEL and LIG) are presented as a percentage of the cell wall material. In general, the pasture was low in overall quality.

The quality of forage selected by animals on all treatments was substantially higher than the overall available pasture (Tables 2 and 3). Obviously the sheep must have been selecting a specific portion of the green fraction to account for this difference, as the total available green material was much lower in IVDMD and crude protein (CP), and higher in cell wall material (CW) than the diet samples. The composition of the $\mathrm{CW}$ was also different, with the available forage $\mathrm{CW}$ containing a greater proportion of cellulose and less hemicellulose than the CW in the diet selected. There was a significant progressive increase in IVDMD and $C P$, and a decline in $\mathrm{CW}$ of diet samples during the 4-day course of the experiment. We assume this was due to a flush of new growth during this time induced by cessation of a drought. Only $17.3 \mathrm{~mm}$ of rain fell between 1 July and 20 August, while $62.5 \mathrm{~mm}$ of rain fell from 21 August to 25 August. Unfortunately, the pasture was not sampled after the experiment to verify this presumed increase in grass growth.

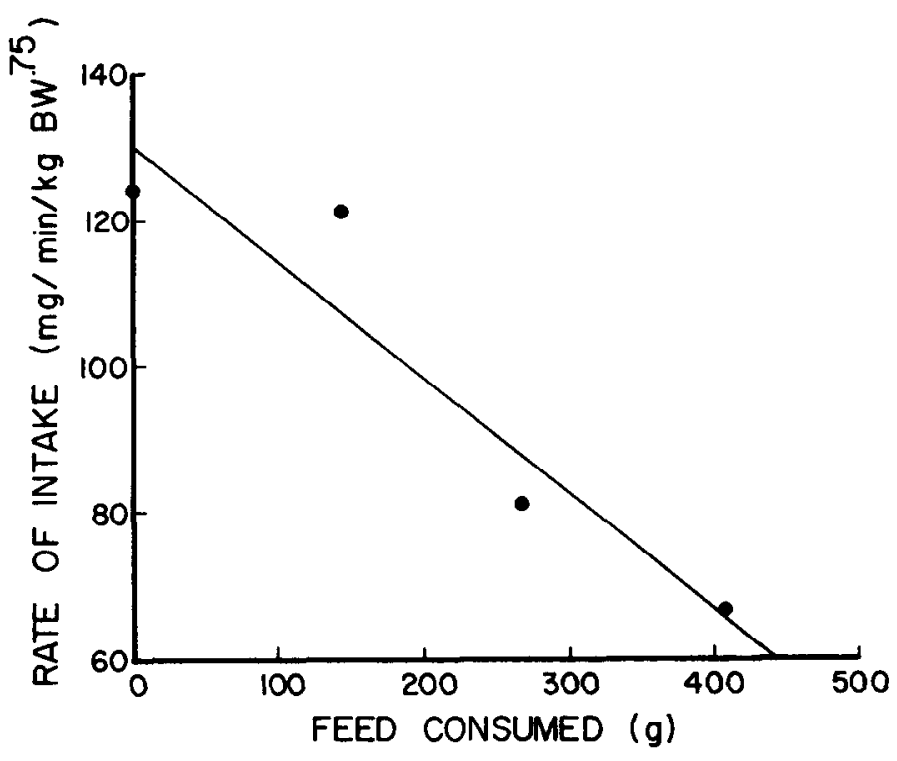

Fig. 1. Relationship of rate of forage intake by grazing esophageal fistulated sheep with quantity of pelleted feed consumed by fasted sheep.

Rate of forage intake was greater for fasted sheep $(0 \mathrm{~g}$ pelleted feed) than for nonfasted animals ( $124 \mathrm{vs} 47 \pm 9 \mathrm{mg} / \mathrm{min} / \mathrm{kg} \mathrm{BW}^{.75}$, $P<.05$ ), but the in vitro dry matter disappearance (IVDMD) of the ingested forage was similar (58.2 vs. $59.5 \pm .8 \%$ ). Sidahmed et al. (1977) observed a similar decline in rate of intake by sheep with progressively shorter lengths of fasting.

In comparing the diet quality of nonfasted sheep with those fasted for $16 \mathrm{~h}(0 \mathrm{~g}$ pelleted feed $)$, the only significant difference was a greater concentration of cellulose in $\mathrm{CW}$ fraction of the forage consumed by the fasted sheep (Table 3). Fasting did not affect IVDMD, CP, and CW of forage selected relative to the nonfasted control. While Arnold et al. (1964) reported that an overnight fast depressed diet quality of fistulated sheep grazing Phalaris tuberosaTrifolium subterraneum pasture, examination of the data on diet

Table 2. Quantity and quality of smooth bromegrass pasture and the green and non-green fractions on 22 August 1983.

\begin{tabular}{|c|c|c|c|c|c|c|c|}
\hline & \multicolumn{4}{|c|}{ Dry matter basis' } & \multicolumn{3}{|c|}{ Cell wall basis ${ }^{2}$} \\
\hline & $\mathrm{kg} / \mathrm{ha}$ & $\begin{array}{l}\text { IVDMD } \\
(\%)\end{array}$ & $\begin{array}{l}\text { CP } \\
(\%)\end{array}$ & $\begin{array}{l}\text { CW } \\
(\%)\end{array}$ & $\begin{array}{l}\mathrm{HC} \\
(\%)\end{array}$ & $\begin{array}{c}\text { CEL } \\
(\%)\end{array}$ & $\begin{array}{l}\text { LIG } \\
(\%)\end{array}$ \\
\hline Pasture & 2826 & 45.3 & 3.7 & 74.8 & 38.8 & 51.9 & 8.5 \\
\hline Green Fraction & 906 & 47.1 & 4.9 & 70.9 & 38.3 & 52.9 & 8.5 \\
\hline Non-green Fraction & 1920 & 43.4 & 3.1 & 78.0 & 39.9 & 50.7 & 8.4 \\
\hline
\end{tabular}

IIVDMD (in vitro dry matter disappearance); CP (crude protein); CW (cell wall).

${ }^{2} \mathrm{HC}$ (hemicellulose); CEL (cellulose); LIG (lignin). 
Table 3. Quality of forage consumed by sheep grazing smooth bromegrass pasture.

\begin{tabular}{|c|c|c|c|c|c|}
\hline \multirow[b]{2}{*}{ Treatment } & \multicolumn{2}{|c|}{ Dry matter basis } & \multicolumn{3}{|c|}{ Cell wall basis ${ }^{1}$} \\
\hline & $\begin{array}{c}\text { Crude protein } \\
(\%)\end{array}$ & $\begin{array}{c}\text { Cell wall } \\
(\%)\end{array}$ & $\begin{array}{l}\mathrm{HC} \\
(\%)\end{array}$ & $\begin{array}{l}\text { CEL } \\
(\%)\end{array}$ & $\underset{(\%)}{\text { LIG }}$ \\
\hline Non-fasted & $16.9^{a}$ & $54.2^{n}$ & 42.3 & $44.8^{n}$ & 8.1 \\
\hline 16 h Fast & $17.7^{\mathrm{a}}$ & $55.3^{\mathrm{a}}$ & 41.8 & $46.6^{b}$ & 8.7 \\
\hline Fast + $135 \mathrm{~g}$ Feed & $16.6^{2}$ & $55.2^{\mathrm{a}}$ & 42.9 & $47.4^{\mathrm{bc}}$ & 8.5 \\
\hline Fast $+271 \mathrm{~g}$ Feed & $21.8^{\mathrm{b}}$ & $49.7^{\mathrm{b}}$ & 41.6 & $47.9^{b c}$ & 8.0 \\
\hline Fast $+407 \mathrm{~g}$ Feed & $22.0^{b}$ & $50.6^{b}$ & 41.2 & $49.0^{c}$ & 7.6 \\
\hline SEM $^{2}$ & 1.2 & 1.0 & .6 & .6 & .3 \\
\hline
\end{tabular}

'HC (hemicellulose); CEL (cellulose); LIG (lignin).

${ }^{2} \mathrm{SEM}$ (standard error of the mean).

${ }^{-{ }^{b}}$ Means in the same column not sharing a common superscript differ $(P<.05)$.

quality revealed that only soluble carbohydrate content was affected. Nitrogen and fiber content of the diet samples did not differ between fasted and nonfasted sheep. Fiber content of sheep diet samples from 4 different pasture types (improved annual grass-clover, native annual grass, perennial grass, and brushland) was the only measurement affected by fasting in a study by Sidahmed et al. (1977) Length of fast did not affect IVDMD or CP of the diet samples. Based upon results of previous research and the current study, it appears that overnight fasting of esophageal fistulated sheep results in diet samples essentially equivalent in quality to those of nonfasted animals.

Consumption of increasing quantities of a highly digestible feed after a fast dramatically affected rate of forage intake and quality of diet chosen by esophageal fistulated sheep. Rate of forage intake (Fig. 1) and IVDMD of the diet sample (Fig. 2) responded in

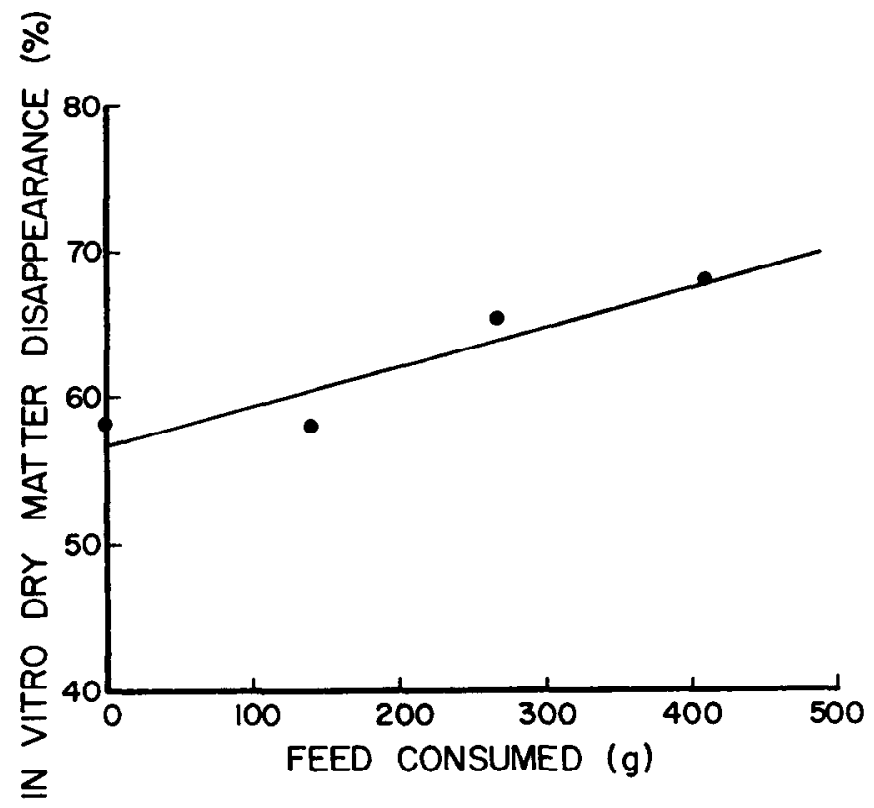

Fig. 2. Relationship of in vitro dry matter disappearance of forage collected by grazing esophageal fistulated sheep with quantity of pelleted feed consumed by fasted sheep.

in opposite directions to increasing consumption of pelleted feed. Rate of forage intake declined [Intake $=\left(-0.156^{*}\right.$ Feed Consumed $)$ $\left.+130, r^{2}=.91, P<.05\right]$ and IVDMD of the dict samples increased $\left[\right.$ IVDMD $=\left(0.026^{*}\right.$ Feed Consumed $\left.)+57.0, r^{2}=.87, P<.05\right]$ as the amount of pelleted feed consumed by sheep fasted for $16 \mathrm{~h}$ increased from 0 to $407 \mathrm{~g}$. Crude protein content of the diet also increased linearly $(P<.05)$, but $\mathrm{CW}$ content declined linearly $(P<.05)$ with increasing intake of feed after fasting. Chemical composition of the $\mathrm{CW}$ consumed also changed linearly, with cellulose content increasing $(P<.05)$ and lignin decreasing $(P<.05)$ with increasing ingestion of the pelleted feed.
Since 2-3 h elapsed between feeding and collection of diet samples, appreciable production of volatile fatty acids should have begun from fermentation of the pelleted feed. Therefore, the reduction in rate of forage intake and increase in selectivity for diet quality could have been caused by bulk fill and/or chemostatic feedback. In either case, increasing satiation of hunger with a highly digestible feed significantly increased diet quality selection by sheep. This result is in agreement with the effects of satiation on diet selection by fish (Ivlev 1961). Based on this study, we assume that sheep will become more selective during the course of a grazing period as physical and/ or chemical feedback mechanisms signal satiation of the animal's hunger. If this assumption is correct, then diet samples collected by fasted sheep represent the minimal estimated quality of forage consumed by animals grazing a highly digestible forage.

An interesting question raised in this study is why did the nonfasted sheep have a rate of forage intake similar to the fasted animals fed $407 \mathrm{~g}$ of pelleted feed, but diet quality equivalent to that of sheep fasted $16 \mathrm{~h}$ with no subsequent feed? Since the nonfasted sheep probably grazed at dawn $(0630 \mathrm{~h})$, as is common for sheep during hot summer months (Dulphy et al. 1980), we assumed that their rumens were relatively full and we expected both rate of forage intake and quality of diet selected to correspond to a single level of feed consumed. The disparity seen does raise the possibility that control of rate of forage intake and diet quality selection are at least partially independent of one another, and are affected by feed quality. Since the rumens of both fasted sheep that were fed pelleted feed and the nonfasted sheep were relatively full, and they had low rates of forage intake, it appears that physical fill may be responsible for control of rate of forage intake. In contrast, only the fasted sheep fed a highly digestible pelleted feed exhibited increased diet quality. This suggests that chemostatic feedback from rumen fermentation products is responsible for control of diet quality selection. The forage consumed by nonfasted sheep was lower in quality than the pelleted feed used in this study, therefore, the amount of chemostatic feedback was less for nonfasted animals, which may explain the lack of a response in diet quality between fasted ( $0 \mathrm{~g}$ pelleted feed) and nonfasted sheep. The question of different mechanisms of control for rate of forage intake and diet quality selection is being addressed in subsequent research.

\section{Literature Cited}

Arnold G.W. 1960. Selective grazing by sheep of two forage species at different stages of growth. Aust. J. Agr. Res. 11:1026-1033.

Arnold, G.W. 1964. Factors within plant associations affecting the behavior and performance of grazing animals. p. 133-154. In: D.J. Crisp (ed.) Grazing in Terrestrial and Marine Environments, Blackwell Scientific Pub., Oxford.

Arnold, G.W., W.R. McManus, I.G. Bush, and J. Ball. 1964. The use of sheep fitted with oesophageal fistulas to measure diet quality. Aust. J. Agr. Res. 4:71-79. 
Dulphy, J.P., B. Remond, and M. Theriez. 1980. Ingestive behavior and related activities in ruminants. p. 103-122. In: Y. Ruckebusch and P. Thivend (eds.) Digestive Physiology and Metabolism in Ruminants, AVI Publishing Co., Inc., Westport, Conn.

Goering, H.K., and P.J. Van Soest. 1970. Forage fiber analysis (apparatus, procedures and some applications). USDA Agr. Handb. 379, Washington, D.C.

Grifrin, J.L., and G.A. Jung. 1983. Leaf and stem forage quality of big bluestem and switchgrass. Agron. J. 75:723-726.

Ivlev, V.S. 1961. Experimental ecology of the feeding of fishes. Yale Univ. Press, New Haven, Conn
Sidahmed, A.E., J.G. Morris, W.C. Weir, and D.T. Torell. 1977. Effect of the length of fasting on intake, in vitro digestibility and chemical comosition of forage samples collected by esophageal fistulated sheep. J. Anim. Sci. 46:885-890.

Terry, R.A., and J.M.A. Tilley. 1964. The digestibility of the leaves and stems of perennial ryegrass, cocksfoot, timothy, tall fescue, lucerne and sainfoin, as measured by an in vitro procedure. J. Brit. Grassland Soc. 19:363-372.

Tilley, J.M.A., and R.A. Terry. 1963. A two-stage technique for the in vitro digestion of forage crops. J. Brit. Grassland Soc. 18:104-111.

Van Dyne, G.M., and D.T. Torell. 1964. Development and use of the esophageal fistula: a review. 17:7-19. 